\title{
All Power to the Experts? Contradictions of the Information Society as Both Depending on and Devaluating Expertise*
}

\author{
NICHOLS T. (2017). THE DEATH OF EXPERTISE: THE CAMPAIGN AGAINST ESTABLISHED KNOWLEDGE AND WHY \\ IT MATTERS. NEW YORK: OXFORD UNIVERSITY PRESS. 272 P. ISBN 978-0-19-046941-2 ${ }^{1}$
}

\author{
Irina Trotsuk \\ DSc (Sociology), Professor, Sociology Chair, RUDN University \\ Leading Research Fellow, Center for Fundamental Sociology, \\ National Research University - Higher School of Economics \\ Address: Miklukho-Maklaya str., 6, Moscow, Russian Federation 117198 \\ E-mail: irina.trotsuk@yandex.ru
}

Strange things did happen here No stranger would it be...

Mockingjay's Haunting Song

Today, we live in a very unpredictable and uncomfortable world, which would have seemed almost impossible a year ago when the lack of travel and total social distancing were unimaginable. There are tons of preprints, articles and even books (already!) on the different phenomena and issues of the notorious 2020. ${ }^{2}$ This is normal for the expert community to question and discuss prerequisites, courses, and consequences of current events. It is just as understandable for ordinary people to either lash out between the con-

\footnotetext{
* Статья опубликована в рамках исследовательского проекта «Этика солидарности и биополитика карантина: теоретические проблемы культурно-политических трансформаций в эпоху пандемий», реализуемого ЦФС в 2021 году в соответствии с Программой фундаментальных исследований НИУ ВШЭ.

1. I have not read the Russian translation published in 2019. According to some readers' reviews on the Internet bookshops' web-sites, the book is considered too simple and trivial even for a non-fiction edition. I am not sure if such a perception is determined by the translation style or the author's clear argumentation that was mistaken for a lack of scientific rigor. However, if the reader accepts the author's idea of "enlightening" the public of the true and ever-lasting value of authoritative knowledge with convincing illustrative cases and clear arguments, and if the reader uses a bit of sociological imagination, the book's "as-if" simplicity would seem a hard-won fabric for explaining contradictory realities. Such books definitely improve one's sociological "optics" and support the argument that science (and sociology in particular) must not be defined as art, despite the imagination needed. Moreover, the notorious 2020, especially the pandemic, might have changed the readers' first perception of the book, for it shows the essence of the general distrust in expertise, the consequences of which we all watch and experience.

2. My author's privilege will be used so as not to make huge references for every statement. For instance, in this case, I would need a huge space to mention only the Russian sociological surveys of university teachers on the advantages and disadvantages of online education under the pandemic restrictions, not to mention other issues or other countries or global challenges of a medical, economic, or social nature.
} 
tradictory expert opinions provided by TV shows and social media or, on the contrary, to hold on to their chosen perspective regardless of other arguments.

The chaotic nature of contemporary life with some (not always predictable and rational) exaggerated forms of as-if-based-on-science state control (or rather attempts to control) were in one way or another predicted and described many times. Just a secondlong Google search would provide many famous scientists' quotes on the disappointment in science for not ensuring the level of knowledge, the accuracy of predictions, and the scope of security we so much strive for. ${ }^{3}$ Albert Einstein believed that "for the most part we humans live with the false impression of security and a feeling of being at home in a seemingly trustworthy physical and human environment. But when the expected course of everyday life is interrupted, we are like shipwrecked people on a miserable plank in the open sea, having forgotten where they came from and not knowing whither they are drifting. But once we fully accept this, life becomes easier and there is no longer any disappointment". ${ }^{4}$

Unfortunately, such acceptance is accessible primarily (and perhaps, exclusively) to scientists who understand both the limits of our mental weapons and the self-correcting nature of science (lost favored hypotheses and proven inadequate, chagrined theories), and find positive lessons in refutation (according to Karl Popper). ${ }^{5}$ For scientists as literal experts - "dangerous people who actually know what they are talking about", ${ }^{6}$ the correction of certain errors is a more proper operation of science providing a deeper insight into a methodology than the as-if-final establishment of truth (and is actually just as probable). However, the public prefers clear instructions on what to do and (at least until very recently) trusts scientists and the government as relying on expert opinions. The notorious 2020 puts us not only in an objectively new social-economic-geographical-political situation, but also cuts the ground out from our trust in expertise which became too various, diverse, and contradictory on almost all socially-urgent issues. We were made personally responsible for difficult choices in the spheres we are not competent in by definition, and not capable of controlling the outcomes of our decisions (such as health protection, medical treatment, emergency calls and hospitalization, social distancing and security, and so on). ${ }^{7}$

3. See, e.g., https://todayinsci.com/QuotationsCategories/D_Cat/Disappointment-Quotations.htm.

4. Einstein A. (2014) The Human Side: Glimpses from His Archives (eds. H. Dukas, B. Hoffmann), Princeton: Princeton University Press, p. 72.

5. See, e.g.: Popper K. R., Miller D. W. (1984) Popper Selections, 1902-1994, Princeton: Princeton University Press.

6. Lawrence Freedman's words on the second page of the reviewed book.

7. See such features of the contemporary society in more detail: "...manipulation is at its most vicious when it turns the blame for the imperfections of the culturally produced life formulae and the socially produced inequality of their distribution on the self-same men and women for whose use the formulae are produced and resources needed to deploy them are supplied. It is then one of those cases when (to use Ulrich Beck's expression) institutions 'for overcoming problems' are transformed into 'institutions for causing problems'; you are, on the one hand, made responsible for yourself, but on the other hand are 'dependent on conditions that completely elude your grasp' (and in most cases also your knowledge); under such conditions, 'how one lives becomes the biographical solution of systemic contradiction'. Turning the blame away from the institutions and onto the inadequacy of the self helps either to defuse the resulting potentially disruptive anger, 
Until quite recently, we had a confident gut feeling that the natural sciences (including medicine) indeed did explain some things due to revealing the systemic manifestations of natural laws with the help of scientific methodology:

\begin{abstract}
The modern world, of course, has long been shaped by the influence of science and scientific discovery. As the pace of innovation hots up, however, new technologies penetrate more and more to the core of our lives; and more and more of what we feel and experience comes under the scientific spotlight. The situation does not lead to increasing certainty about, or security in, the world - in some ways the opposite is true ... The founders of modern science believed it would produce knowledge built on firm foundations. Popper supposes that science by contrast is built on shifting sands. The first principle of scientific advance is that even one's most cherished theories and beliefs are always open to revision. Science is thus an inherently skeptical endeavor, involving a process of that constant revision of claims to knowledge. The skeptical, mutable nature of science was for a long time insulated from the wider public domain ....8
\end{abstract}

It has been a completely different matter with the social sciences. They were accused of many ills such as relying on concepts (power, tolerance, norm, freedom, happiness, etc.) that carry a set of differing perceptions for groups, countries and historical eras; researching either too-macro-problems that cannot be studied empirically and would essentially stay philosophical, or too-micro-problems in a too controlled and artificially designed environment; producing rather tautological assertions and pseudo explanations than critical reflections and practical recommendations necessary for a better understanding of social world and changing it for the better; and, in the first place, for losing its predictive ability (especially sociology, when political choices are concerned). ${ }^{9}$

or to recast it into the passions of self-censure and self-disparagement or even rechannel it into violence and torture aimed against one's own body" (Bauman Z. [200o] The Individualized Society, Malden: Polity Press, p. 5). Thus, we witness "the abandonment of the individual to the lonely struggle with a task with which most individuals lack the resources to perform alone" (Ibid.: 6). See also: Flint J., Powell R. (2013) Individualization and Social Dis/integration in Contemporary Society: A Comparative Note on Zygmunt Bauman and Norbert Elias. Norbert Elias and Social Theory (eds. F. Dépelteau, T. S. Landini), New York: Palgrave Macmillan, pp. 261-274.

8. Giddens A. (1999) Risk and Responsibility. Modern Law Review, vol. 62, no 1, p. 1.

9. See, e.g., Dropp K. (2016) How We Conducted Our "Shy Trumper" Study. Available at: https://morningconsult.com/2016/11/03/shy-trump-social-desirability-undercover-voter-study; Kennedy C., Keeter S., Hatley N., Lau A. (2017) Are Telephone Polls Understating Support for Trump? Available at: https://www. pewresearch.org/methods/2017/o3/31/are-telephone-polls-understating-support-for-trump; Vavreck L. (2015) Survey Mode Effects: A Randomized Experiment. Available at: http://www.aapor.org/AAPOR_Main/media/ AnnualMeetingProceedings/2015/C1-2-Vavreck.pdf; McQuarrie M. (2016) Sociology has a Trump Problem. Available at: https://blogs.lse.ac.uk/researchingsociology/2016/11/17/sociology-has-a-trump-problem; Silver N. (2016) The State of the Polls. Available at: https://fivethirtyeight.com/features/the-state-of-thepolls-2016; Cox D. A. (2020) Could Social Alienation among Some Trump Supporters Help Explain Why Polls Underestimated Trump Again? Available at: https://www.americansurveycenter.org/commentary/couldsocial-alienation-among-some-trump-supporters-help-explain-why-polls-underestimated-trump-again; Matthews D. (2020) One Pollster's Explanation for Why the Polls Got It Wrong. Available at: https://www. vox.com/policy-and-politics/2020/11/10/21551766/election-polls-results-wrong-david-shor; Lavrakas P. J. (2013) Presidential Address: Applying a Total Error Perspective for Improving Research Quality in the So- 
To conclude this protracted introduction to the review, let us summarize some features of the obvious public discontent and distrust in science which were widely discussed long before the pandemic; (1) science did not manage to explain everything and equip us with precise instructions and technologies to live a wealthy and secure life, which cannot but upset; (2) we still (at least before the pandemic) had more trust in natural sciences than in social ones due to various reasons, in particular to the latter's greater floor for politically-biased interpretations and fake data; (3) there have been established intra-disciplinary discourse and debates on the explanatory limits of science and a rather outer-scientific critique of sociological research and social technologies, i.e., there was not a general line for discussing the possibilities and limitations of scientific expertise and factors affecting its reliability and credibility. Despite these features of the sciencesociety relationship having been admitted, it was quite impossible to predict the social, political, and economic events and the pandemic of 2020. To understand the situation in its objective and interpretational dimensions, we need both the insights made before the current global crisis and the insights not only confined to the scientific debates but having the social grounds to explain more than their authors would claim (concerning cases considered). The book by Tom Nichols is an example of such an insight applicable to a wider context than the threats to social trust and democracy in the Unites States.

According to the reviewers, with whom one cannot disagree, the book is a "compelling, and often witty polemic", showing that in our "post-fact age", "the digital revolution, social media, and the Internet have helped to foster a cult of ignorance". Therefore, the author considers "what might be done to get authoritative knowledge taken more seriously", how to return "reason and rationality in our public and political discourse", and how to "balance our skepticism with trust going forward" (p. ii). Certainly, these are not issues specific to the American society, which makes the book interesting for a much wider audience that would see similarities in the challenges and prospects described. The general framework of the author's narrative is the death of expertise as a result of the de-

cial, Behavioral, and Marketing Sciences. Public Opinion Quarterly, vol. 77, no 3, pp. 831-850; Baidakova A., Komin M., Almamatov A., Alexeev A. (2015) Faktory nedostovernosti rezul'tatov sociologicheskih oprosov [Factors of Unreliability of the Sociological Surveys Results]. Available at: http://www.cogita.ru/a.n.-alekseev/ andrei-alekseev-1/faktory-nedostovernosti-rezultatov-sociologicheskih-oprosov; Meduza (2016) Za chto my nenavidim socoprosy: chetyre glavnyh pretenzii k rassuzhdenijam o "bol'shinstve rossijan" [Why We Hate Opinion Polls: Four Main Complaints about the "Majority of Russians"]. Available at: https://meduza.io/feature/2016/o1/14/za-chto-my-nenavidim-oprosy-obschestvennogo-mneniya; Filina O. (2015) Sociologicheskaja pogreshnost': pochemu oprosy obshhestvennogo mnenija vyzyvajut stol'ko voprosov [Sociological Error: Why Opinion Polls Raise So Many Questions]. Available at: https://www.kommersant.ru/doc/280o149; etc. 
velopment of the expert ${ }^{10}$-laypeople relationship ${ }^{11}$ in recent decades: the book describes the factors and consequences of such a development in higher education, social communication (primarily electronic), and journalism, and finishes with the political dimension of the death of expertise.

There is no point in reconstructing the logic of the author's argumentation by sections, so let us summarize the main book's ideas, or rather, its implicit questions. The first question is what is going on with the social functioning of knowledge? The author argues that the Unites States is obsessed with the worship of its own ignorance (certainly, not only the U.S.), and the problem is not the ignorance itself since people have never known much and will never know much about science or politics, which is an old and eternal social problem. Nothing much has changed since Emile Durkheim described the social division of labor ${ }^{12}$ as the essence of social organization: "We live in a society that works because of a division of labor, a system designed to relieve each of us of having to know about everything... None of us is a Da Vinci, painting Mona Lisa in the morning and designing helicopter at night [there are such people but they are exceptions]" (p. x). Nichols misses the personal responsibility for the decisions we make in the spheres we are not competent in (due to the as-if-relieving social division of labor), but in general the picture is true.

I am not sure that people are really "proud of not knowing things", consider "ignorance, especially of anything related to public policy, an actual virtue", and "reject the advice of experts to assert autonomy" - these are exaggerations summarized in the metaphor of a new Declaration of Independence and similar to the accusation of Americans in the "traditional distaste for intellectuals and know-it-alls" - "most people do not like professors" (p. x). However, while the description is exaggerated, the underlying diagnosis is correct: expertise as a combination of scientific authoritative knowledge and principled, informed arguments is in danger. The problem is not questioning expertise and its grounds since this is absolutely normal for the development of knowledge. The problem is people's aggressive protection of their ignorance and their refusal to learn anything that contradicts their groundless beliefs. One cannot disagree that we all have had such an ex-

10. The author does not divide the terms "experts", "professionals", and "intellectuals" (p. 14), which does not seem to be a correct decision but does comply with the aims of the book. Later, on page 29 , he emphasizes the interchangeability of three words as defining people who "have mastered particular skills or bodies of knowledge and who practice those skills or use that knowledge as their main occupation in life" (specialization is necessarily exclusive and talent is indispensable). He continues: "Another mark of true experts is their acceptance of evaluation and correction by other experts" (self-policing, peer-run institutions to maintain standards and to enhance social trust) (p. 35).

11. The author does not clarify his interpretation of "experts" and "laypeople", although the relationship of these two terms has long been the focus of scientific searches and debates. See, e.g., Kangas I. (2002) "Lay" and "Expert": Illness Knowledge Constructions in the Sociology of Health and Illness. Health, vol. 6, no 3, pp. 301-304; Maranta A., Guggenheim M., Gisler P., Pohl C. (2003) The Reality of Experts and the Imagined Lay Person. Acta Sociologica, vol. 46, no 2, pp. 150-165; McClean S., Shaw A. (2005) From Schism to Continuum? The Problematic Relationship between Expert and Lay Knowledge - An Exploratory Conceptual Synthesis of Two Qualitative Studies. Qualitative Health Research, vol. 15, no 6, pp. 729-749.

12. See, e.g., Durkheim E. (1984) The Division of Labor in Society, New York: The Free Press; Merton R. K. (1934) Durkheim's Division of Labor in Society. American Journal of Sociology, vol. 40, no 3, pp. 319-328. 
perience when people without the first clue about the subject at hand would confidently direct you on how to do something (the easiest way to check it is to post something on a social network).

In general, having discussions is understandable and desirable in public policy and social communication, and laypeople are often asked for their opinions. However, the scope of laypeople's "expertise" today has widened tremendously. Instead of asking doctors, lawyers, teachers, etc., sensible questions, clients, patients, students, etc., tell professionals why their advice is wrong and dismiss the very idea of the expert's better knowing almost out of hand too often, on too many issues, and with too much anger. It is very difficult "for experts to push back and to insist that people come to their senses ... Instead of arguing, experts today are supposed to accept disagreements [with incompetent but stubborn laypeople] as, at worst, an honest difference of opinion ... to 'agree to disagree"' (p. xi). It is difficult to agree with the author's explanation of the situation that the reason is either "narcissism coupled to a disdain for expertise as some sort of exercise in selfactualization" or "merely a symptom of generational change" (Ibid.). Undoubtedly, both matters, in particular, the generational differences in the degree of respect and trust in science and politics. However, on the one hand, as Nichols rightly notes, this trust "was not only misplaced but abused" for decades. On the other hand, which he rather ignores, there is a factor of the socially-imposed personal responsibility for decisions people are not competent enough to make. This makes them wonder why their opinion matters in elections and vaccination but not in other spheres, since they are as "competent" in them as in the ones they are asked to make choices in.

The second implicit question of the book is what are manifestations of the death of expertise? The author quotes Isaac Asimov's words on anti-intellectualism as "a constant thread winding its way through our political and cultural life, nurtured by the false notion that democracy means that 'my ignorance if just as good as your knowledge"' (p. 1). "AIDS denialists" are mentioned as an example of anti-intellectualism that argued against virtually the entire medical establishment's consensus and had tragic consequences. The model of such a principal and practical denial was reproduced by "COVID-19 denialists" (or "COVID-19-pandemic denialists"). The author provides many examples of people being too confident in their abilities to judge and make decisions while being absolutely ignorant of the matter, such as on their country's military intervention in a conflict while not being able to identify the geographic location of the proposed mission (their enthusiasm for military intervention was in direct proportion to their lack of knowledge), on the nature of gluten while avoiding it, on the functions and structure of vaccines while acting as anti-vaccine crusaders, and so on.

The author accepts some "skepticism towards experts" due to "a Google-fueled, Wikipedia-based, blog-sodden collapse of any division between professionals and laypeople", but not the whole situation when "increasing numbers of laypeople lack basic knowledge, reject fundamental rules of evidence and refuse to learn how to make a logical argument", thus, risking of "throwing away centuries of accumulated knowledge" (p. 3). The picture is threatening to the level of sometimes turning into the amusing and even the hilarious; 
in many countries, "comedians have made a cottage industry of asking people questions that reveal their ignorance about their own strongly hold ideas, their attachment to fads, and their unwillingness to admit their own cluelessness about current events" (Ibid.). However, when life and death are involved, there is no space for fun, but uninformed celebrities and public figures propagate myths and misinformation.

We still trust doctors, lawyers, consular officials and many others when we run into trouble, but only as technicians, that is, to use their "established knowledge as an offthe-shelf convenience as needed and only so far as desired" (p. 4), i.e., without a proper dialogue between experts and the larger community. Nichols does not blame only the ignorant public, although the emphasis of the book is definitely on the rejection of existing knowledge, science, and dispassionate rationality by laypeople who believe themselves to be "experts on everything". They "immediately complain that any assertion of expertise from an actual expert is nothing more than fallacious 'appeals to authority', sure signs of dreadful 'elitism', and an obvious effort to use credentials to stifle the dialogue required by a 'real' democracy ... It is a flat assertion of actual equality that is always illogical, sometimes funny, and often dangerous" (p. 5). However, there are things to blame experts for: many of them, especially in academia, prefer to stay in "ivory towers", retreating into scientific terminology and interact only with their "equals" in knowledge and rigor, while public intellectuals are becoming as frustrated and polarized as the rest of society (which is proved by the tons of junk non-fiction books).

In Russia, there is an additional explanation for laypeople's political apathy and intellectual ignorance, which might be less applicable to the United States. This is the strong general belief that ordinary people cannot change anything, so why bother and try: if I cannot affect the social situation and make myself heard by those "on the top", then I would focus on my own life (close social circle or local community) and would not allow experts to tell me how to live my life. ${ }^{13}$ There are probably manifestations of the same phenomenon in American society, but the author does not mention any. Nichols admits the global problem by quoting Robert Hofstadter: "the complexity of modern life (legislation, taxes, healthcare, etc.) has steadily whittled away the functions the ordinary citizen can intelligently and competently perform for himself ... Once the intellectual was gentry ridiculed because he was not needed; now he is fiercely resented because he is needed too much" (p. 18-19). In particular, in America (and globally), this has made it extremely difficult for voters to monitor and evaluate the government's activities: "the low level of political knowledge ... is still one of the best-established findings in social science" (Ibid.), although in Russia, it is accompanied by the low level of political interest and activity.

13. See, e.g., Pozanenko A. (2019) Prostranstvennaja izoljacija i ustojchivost' lokal'nyh soobshhestv: k razvitiju sushhestvujushhih podhodov [Spatial Isolation and Sustainability of Local Communities: Development of Existing Approaches]. Puti Rossii: granitsy politiki [Paths of Russia: Boundaries of Politics] (ed. M. Pugacheva), Moscow: New Literary Observer, pp. 139-153; Zubarevich N. (2011) Chetyre Rossii [Four Russias]. Available at: https://www.vedomosti.ru/opinion/articles/2011/12/30/chetyre_rossii. 
The third question of the book is why "so many people having so much access to so much knowledge are yet so resistant to learning anything, ... why otherwise intelligent (adept, successful) people denigrate intellectual achievement and reject the advice of experts" (p. 3), that is, what are the factors of the death of expertise? As seen in the Introduction, the author refuses to blame the Internet because this is not the only explanation; the Internet is the most recent tool which has substituted other media in a recurring problem. Although the author suggests dividing the sources of the death of expertise into three groups - rooted in human nature, unique to America, and unavoidable for modernity and affluence - these sources have become so global and so similar in different nations that there is no point in identifying their national specifics.

(1) The age-old problem of the relationship between experts and laypeople has transferred its basic contradictions to social communication in general, despite the "status" of interlocutors. For instance, confirmation bias - the tendency ${ }^{14}$ to accept evidence that confirms our principal beliefs - and the lack of knowledge prevents us from recognizing the gaps in our worldview, and from understanding and admitting our inability to construct a logical argument. Confirmation bias is common for all people, regardless of their knowledge and competence: we tend to "look for information that only confirms what we believe, accept facts that only strengthen our preferred explanation, and dismiss data that challenge what we already accept as truth" (p. 47). Concerning science, "even though every researcher is told that 'a negative result is still a result', no one really wants to discover that their initial assumptions went up in smoke" (p. 51).

We all know people who believe they are troves of knowledge and are more than happy to enlighten the rest of us about everything. In our everyday life, we even have a certain affection for them (if they are our relatives). However, the problem is that "the public sphere is increasingly dominated be a loose assortment of poorly informed people, many of them autodidacts who are disdainful of formal education and dismissive of experience... We now live in an age where misinformation pushes aside knowledge" (p. 14). The fatal redundancy of information is an essential feature of the information age, which determines the low levels of knowledge among laypeople (a historical fact). The problem is not indifference but a positive hostility to established knowledge, and its replacement by the principles of "every opinion matters" or "every opinion is as good as every other" (proclaimed anti-intellectualism).

The author believes that such a devaluation of expert knowledge undermines the very foundations of social order based on a social division of labor and a reliance on experts: society "cannot function [properly or normally] without admitting the limits of our knowledge and trusting in the expertise of others" (p. 15). The current situation is different from the traditional intellectuals' complaints about the denseness and distrust of their fellow citizens, amplified by the Internet and social media which gather factoids and halfbaked ideas and spread misinformation and poor reasoning, and from traditional persistent attachments to both harmless and dangerous folk wisdom, superstitions, urban leg-

14. The definition "natural tendency" seems unacceptable; there is nothing "natural" in it since this is a socially acquired pattern of interaction. Therefore, the term "natural" is omitted. 
ends, and intricate conspiracy theories. The author touches upon the issue of populism when arguing that "in the original American populistic dream, the omnipotence of the common man was fundamental and indispensable; it was believed that he could, without much special preparation, pursue the professions and run the government" (p. 18). This is a very difficult topic regaining popularity, ${ }^{15}$ which was simply mentioned in passing but could have been used as a basis for explaining the political "dimension" of the death of expertise.

Another problem is that "experts are not infallible and have made terrible mistakes with ghastly consequences" (p. 10) as a result of outright fraud, well-intentioned but arrogant overconfidence, and the usual mistakes we all make. However, experts monitor their work and themselves, and should not be attacked by laypeople for being incompetent. Laypeople mistake the occasional experts' failures in certain issues (with catastrophic consequences) for the fact that experts are consistently wrong on everything, thus disregarding any expert advice they do not like. Nichols writes: "It rarely occurs to skeptics that for every terrible mistake, there are countless successes" (p. 24). Laypeople tend to forget that (a) experts make far fewer mistakes that a layperson, because they know the pitfalls of their profession better; (b) knowing a little bit does not means "expertise" (comprehension) - it requires education, training, practice, experience, and acknowledgement by others in the field; (c) we are social animals who want acceptance and affection, and we might mistake the support of those closest to us for our amazing competency and trustworthiness; (d) formal education is not a sufficient indicator of expertise or of becoming smarter and more intelligent; (e) most of the time, in day-to-day matters, we do not need scientific methods and data because common sense serves us well (therefore, we dwell in the illusion that the tools of common sense are sufficient and will not betray us in untangling complicated issues); (f) resisting generalization, because we all want to believe that we are unique, does not cancel generalization as the root of science (by the way, resistance to scientific generalization as probabilistic explanation happily coexists with the ugly social habit of stereotyping and stigmatization); (g) the "Dunning-Kruger Effect" cannot be ignored or underestimated - "people spool off on subjects about which they know very little and with completely unfounded confidence" (p. 43), i.e., "the dumber (unskilled or incompetent) you are, the more confident you are

15. See., e.g., Badiou A. (2016) Twenty-Four Notes on the Uses of the Word "People". Badiou A., Bourdieu P., Butler J., Didi-Huberman G., Khiari S., Rancière J., What is a People?, New York: Columbia University Press, pp. 21-31; Edelman M. (2020) From "Populist Moment" to Authoritarian Era: Challenges, Dangers, Possibilities. Journal of Peasant Studies. Available at: https://doi.org/10.1080/03066150.2020.1802250; Pain E., Fedyunin S. (2019) Populizm i jelitizm v sovremennoj Rossii: analiz vzaimosvjazi [Populism and Elitism in Contemporary Russia: Analysis of the Relationship]. Political Studies, no 1, pp. 33-38; Gudkov L. (2017) Osobennosti rossijskogo populizma [Peculiarities of the Russian Populism]. Bulletin of Public Opinion, no 1-2, pp. 91-105; Moffitt B. (2016) The Global Rise of Populism: Performance, Political Style, and Representation, Stanford: Stanford University Press; Roman-Alcalá A. (2020) Agrarian Anarchism and Authoritarian Populism: Towards a More (State-)Critical "Critical Agrarian Studies". Journal of Peasant Studies. Available at: https:// doi.org/10.1080/03066150.2020.1755840; Scoones I., Edelman M., Borras S. M., Hall R., Wolford W., White B. (2018) Emancipatory Rural Politics: Confronting Authoritarian Populism. Journal of Peasant Studies, vol. 45, no 1, pp. 1-20; etc. 
that you are not actually dumb; we all overestimate ourselves, but the less competent do it more than the rest of us" (p. 44); (h) "social pressure has always tempted even intelligent, well-informed people to pretend to know more than they do, but this impulse is magnified in the Information Age" (66); moreover, "we can take being wrong about the kind of bird we just saw in our backyard, or who the first person was to circumnavigate the globe, but we cannot tolerate being wrong about the concepts and facts that we rely upon to govern how we live our lives" (p. 67).

Although, in general, the "Dunning-Kruger Effect" is considered to be specific for laypeople, experts often make a similar mistake: when people "have no idea what they are talking about, it does not deter them from talking anyway" (p. 45). Experts sometimes cannot resist giving an opinion, and try to stretch their expertise from one area to another so as to answer a need in the public square. According to Nichols: "This is not only a recipe for error, but is maddening to other experts as well. In some cases, the cross-expertise poaching is obvious, as when entertainers - experts in their own fields, to be sure - confuse art with life and start issuing explanations of complicated matters" (p. 177). He continues: "Yet another problem is when experts stay in their lane but then try to move from explanations to prediction" to satisfy the society's demand in predictions of discrete events, the failures in which this very society regards as "indications of the worthlessness of expertise" (p. 178). "The goal of expert advice and prediction is not to win a coin toss, it is to help guide decisions about possible futures" (p. 203). The author then provides good examples of sociological polls and market research that can get something very wrong.

In addition, especially in difficult conversations on the most controversial issues, experts forget about the requirement to remain dispassionate (in the Weberian sense) ${ }^{16}$ : "Experts must treat everything from cancer to nuclear war as problems to be solved with detachment and objectivity. Their distance from the subject enables open debate and consideration of alternatives, in ways meant to defeat emotional temptations, including fear, that led to bias" (p. 64). Unfortunately, such a level of emotional detachment is not always accessible to experts.

Still another problem is that people tend to confuse experts (advisers) and policymakers (deciders), which corrodes trust among the public, experts, and officials. Policymakers engage experts to advise them, and knowers sometimes do give wrong advice. However, more often, experts cannot make the decider follow their advice, or cannot control how leaders implement them or how much of their advice is taken, i.e., "experts can advise policymakers on what to do, but they may find their advice taken in ways that were never intended" (p. 223).

(2) There is an obvious transformation of education in general and of higher education in particular, from an enlightening institution into a service sector and a generic commodity. Despite the widespread assumption that the broad availability of a college/

16. See, e.g., Weber M. (1946) Science as a Vocation. From Max Weber: Essays in Sociology (eds. H. H. Gerth, C. W. Mills), New York: Oxford University Press, pp. 129-156; Goddard D. (1973) Max Weber and the Objectivity of Social Science. History and Theory, vol. 12, no 1, pp. 1-22. 
higher education would make many people smarter, students (and their parents) have become "valued clients" which determined a market competition of colleges and universities as "producers" of educational services. Thus, students "gain only an illusory intelligence bolstered by a degree of dubious worth, . . . a great deal of self-esteem, but precious little knowledge; worse, they do not develop the habits of critical thinking that would allow them to continue to learn and to evaluate the kinds of complex issues on which they will have to deliberate and vote as citizens" (p. 9). Nichols identifies himself as a beneficiary of a wider access to higher education and the social mobility it provides, and the one who continues to have faith in the ability of postsecondary schools to produce both knowledge and knowledgeable people. However, universities fail to fulfill their main function of developing critical thinking as "the ability to examine new information and competing ideas dispassionately, logically, and without emotional or personal misconceptions" (p. 72).

The reason here is that colleges and universities provide a "full-service experience of going to college" and a feeling of being "educated" rather than knowledge, critical thinking, reasonable background in a subject, and a willingness to continue learning which is due to the increasing commodification of education: students are treated as clients and get the right to evaluate educators, i.e., the layperson becomes accustomed to judging the expert (Ibid.). "In the worst cases, degrees affirm neither education nor training, but attendance ... to an expensive educational buffet laden mostly with intellectual junk food, with very little adult supervision to ensure that the students choose nutrition over nonsense" (p. 74). The situation is the same in many countries: "The emergence of faux universities is in part a response to an insatiable demand for degree in a culture where everyone thinks they should go to college, ... which created a destructive spiral of credential inflation" (grade inflation, degree inflation, collapsing standards, low-quality doctorates, so many PhDs that the academic job market cannot absorb them, etc.) (p. 75). Not only Americans, but Russians, too, "are burying themselves in a blizzard of degrees, certificates, and other affirmations of varying value" (p. 89). The author blames the "industrial model" 17 of education that "reduces college to a commercial transaction, where students are taught to be picky consumers rather than critical thinkers" (p. 98).

Probably, Nichols misses another important feature of the contemporary youth in that they have become more infantile than previous generations, which affects their demands, expectations, emotions and behavior patterns ${ }^{18}$ for the worse when the independency of learning, argumentation, making decisions and even the search for knowledge is concerned. However, the author emphasizes the role of parents and college in such

17. There is a trend of questioning the efficiency and credibility of the 'industrial' form of organization in general. See, e.g., such questioning in agriculture: Wegren S., Trotsuk I. (2020) Ustojchivo li promyshlennoe sel'skoe hozjajstvo v uslovijah klimaticheskih izmenenij i jekologicheskih ugroz? [Is Industrial Agriculture Sustainable during Climate Change and Ecological Threats?]. Journal of Economic Sociology, vol. 21, no 5, pp. $12-38$.

18. See, e.g., Twenge J. M. (2018) iGen: Why Today's Super-Connected Kids Are Growing Up Less Rebellious, More Tolerant, Less Happy - and Completely Unprepared for Adulthood - and What That Means for the Rest of Us, New York: Atria Books. 
infantilization. Nichols writes that college "is no longer a passage to educated maturity and instead is only a delaying tactic against the onset of adulthood - in some cases, for the faculty as well as for the students" (pp. 73-74); and parents choose the best client-centered college for their child, i.e., "not escorting him/her away from adolescence" (overprotective and over-helping "helicopter parenting"). ${ }^{19}$

(3) At the same time, the Internet (and electronic media in general) as a "source and enabler of a spreading epidemic of misinformation" and a "platform for attacks on established knowledge" (myths and rumors are turned into "facts" and stay online for years), and despite being a "defense against them" and a "magnificent repository of knowledge", contributes to the death of expertise and to the eroding respect for experts. However, "the Internet is not the primary cause of challenges to expertise, but rather has accelerated the collapse of communication between experts and laypeople by offering an apparent shortcut to erudition. It allows people to mimic intellectual accomplishment by indulging in an illusion of expertise provided by a limitless supply of facts" (p. 106). The problem is that access to torrents of information weakens the ability of both laypeople and scholars to do basic research and navigate this "wilderness" of big data: "plugging words into a browser window is not research" (p. 109), and "seeing words on a screen is not the same as reading or understanding them". However, "the very act of searching for information makes people think they have learned something, when in fact they are more likely to be immersed in yet more data they do not understand" (p. 119).

Virtual communication makes people more self-assured (the author prefers words "meaner" and "shorter-fused"). When anonymous or inaccessible in real life, people prefer insults to discussion and listening. Moreover, social media make us less social and more confrontational: we prefer to talk only to those with whom we already agree, and we easily "unfriend", that is, break ties with everyone we are not associating with. In addition, social media are a "great equalizer": for instance, students communicate with teachers as with a customer-service department that is reachable with only a few keystrokes. In general, "in the age of social media, people using Internet assume that everyone is equally intelligent or informed merely by virtue of being online" (p. 129). What is more dangerous is that "the Internet is changing the way we read, the way we reason, even the way we think, and all for the worse" (p. 109). The author makes the pessimistic conclusion that "there is no way to enlighten people who believe they have gained a decade's worth of knowledge because they have spent a morning with a search engine" (120), albeit gravitating toward and believing whichever results of a search come up first in the rankings. ${ }^{20}$

(4) In the contemporary hyper-competitive environment that affected all social institutions, including previously conservative higher education, the media's priority has changed from informing to entertaining. Instead of developing expertise or deep

19. For decades, such parenting (in Russia) was considered the principal difference between the U.S. and Russia; this is truly amazing that today the two societies converge in overprotective parenting.

20. This is a new manifestation of the "spiral of silence". See Noelle-Neumann E. (1974) The Spiral of Silence: A Theory of Public Opinion. Journal of Communication, vol. 24, no 2, pp. 43-51. A list of recent citing literature based on the concept can be found at: https://onlinelibrary.wiley.com/doi/abs/10.1111/j.1460-2466.1974. tboo367.x. 
knowledge of a subject, journalists and experts are "often reduced to sound bites or 'pull quotes"' (p. 10). The author argues that, for decades, we used to consider reporters as capable of digging out the truth, as "arbiters of all this chaos", equipped with tools of investigation, sourcing, and fact-checking. Today, "in a world of constant information, delivered at high speed and available twenty-four hours a day, journalism is sometimes as much a contributor to the death of expertise as it is a defense against it" (p. 137). There are good and bad journalists: the former help people make sense of the complicated world, while the latter do not, thus, increasing threats to expertise and established knowledge. Anyway, the "banquet of information, served up with various kinds of garnish on any number of platters", accessed easily and shared electronically, is just too much and too closely fused with entertainment. Therefore, being drowned in data, suffering from information overload, and being tired of listening to would-be experts speaking on anything and everything on all platforms, "people remain resolutely ignorant and uninformed, and reject news, even when it is all delivered to them almost without effort" (p. 139).

The last question of the book is what to do in the situation of the death of expertise? Although the experts' fault is not the basis of the author's argumentation but a peripheral storyline, Nichols calls experts to action to change the situation for the better. The author insists that the experts' duty is to make important issues understandable to laypeople, and to serve society by educating and enlightening it, regardless of how their fellow citizens behave. However, society's responsibility is to learn, to develop critical thinking and, when approaching the news, to be humbler (accept others being more competent), ecumenical (use different sources of information), less cynical, and more discriminating (search for answers and raise questions) (p. 167). Metaphorically, this is a model of an "expertise-positive" (instead of "ignorance-positive") society demanding an experts' rebel to reassert their authority. Thus, university teachers should resist the entire notion of education as a client service; experts should learn to say "no" when asked to give an opinion on anything beyond their field, and remember their responsibility to demur; public intellectuals should shoulder more responsibility in bridging the gap between experts and laypeople, and laypeople should take more responsibility for their own knowledge. Nichols writes that "it is no excuse to claim that the world is too complicated and there are too many sources of information, and then to lament that policy is in the hands of faceless experts who disdain the public's views" (p. 207). He also writes: "Both experts and laypeople have responsibilities when it comes to expert failures. Professionals must own their mistakes, air them publicly, and show the steps they are taking to correct them. Laypeople, for their part, must exercise more caution in asking experts to prognosticate, and they must educate themselves about the difference between failure and fraud" (p. 205).

Perhaps, the main feature of the book that would both upset and inspire its nonAmerican reader is its over-exaggerated emphasis on the American democratic culture as contributing to the death of expertise. All societies pass through the same processes of becoming (virtual) noisy public places full of misinformation and challenges to established knowledge. This is not an American privilege. For instance, the author's estimate 
that the death of expertise threatens the material and civil well-being of people does not need a clarification "in a democracy", because the public's aggressive ignorance is a threat to every social system. It is probable that the American "intense focus on the liberties of the individual enshrines resistance to intellectual authority even more" (p. 16), but online anti-intellectualism strengthens its position worldwide.

In addition to the already-mentioned clearness of the author's argumentation, the book has other distinctive features: convincing examples from both science (in particular, sociological research) and personal experience, clarifying and supporting quotes from both academic writings and media discourse which remind the reader from any country of one's national analogues of the described manifestations of the death of expertise; a skillful choice of metaphors; ${ }^{21}$ and inspiring optimism manifested in calls to action. These features allow Nichols not so much to scare or blame laypeople (for ignorance, anti-intellectualism, etc.) as to make them look at and see what is really going on. Concerning experts, the author is, on the one hand, pessimistic for they are defeated by the public's resolute ignorance, while on the other hand, he sees signs of experts rebelling against attacks on their expertise.

While reading the book, an expert-reader would constantly think of theories, concepts, examples, and issues that the author could have but did not consider or mention. For instance, the issue of experts' mistakes corresponds to Ulrich Beck's version of risk society, in which risks can only be understood and managed through science (expertise), yet they increasingly call science into doubt. ${ }^{22}$ According to Anthony Giddens, issues of trust, especially in experts and expert systems, are central for a risk society to manage risks; however, expert knowledge is never final, perfect, or reliable, which makes people lose trust in experts. In other words, contemporary risk societies depend both on experts and the decline of trust in expertise and in major social institutions based on expert knowledge. ${ }^{23}$

21. For instance, the author admits that the chosen wording — "the death of expertise" — "grandly announces its self-importance" though expertise actually "is not dead but in trouble"; believes that "a fair number of people, regardless of political affiliation, will shoot the messenger rather than hear something they don't like"; "the great number of people who have been in or near (!) a college think of themselves as the educated peers of even the most accomplished scholars and experts"; "in response to aggressive marketing from tuitiondriven institutions, teenagers from almost all of America's social classes now shop for colleges the way the rest of us shop for cars"; "the only thing more disheartening than finding out these folks [saying they have graduate education and are therefore to be taken seriously] are lying about possessing multiple degrees is to find out that they are telling the truth"; "when education is about making sure clients are happy, college's reliance on evaluations forces weaker or less secure teachers to become dancing bears, striving to be loved or at least liked"; "nothing excuses colleges for allowing their campuses to turn into circuses" due to "increasingly surrendering their intellectual authority not only to children, but also to activists"; "the Internet is like artillery support: a constant bombardment of random, disconnected information"; "the Internet lets a billion flowers bloom, and most of them stink", etc. I am not sure the book would have been published in the U.S. in 2020 due to the author's perception of contemporary activism as based on the idea of leaving no thought unexpressed, no feeling invalidated, and no intellectual exploration needed.

22. See, e.g., Beck U. (1992) Risk Society: Towards A New Modernity, London: Sage; Doyle A. (2015) Introduction: Trust, Citizenship and Exclusion in the Risk Society. Risk and Trust: Including or Excluding Citizens (ed. Law Commission of Canada), Halifax: Fernwood, pp. 7-22.

23. See, e.g., Giddens A. (1990) The Consequences of Modernity, Cambridge: Polity. 
When Nichols calls experts to resist the death of expertise and to continue their enlightening efforts, one can remember John Polanyi's argument that "[intellectual courage is] the quality that allows one to believe in one's judgement in the face of disappointment and widespread skepticism; intellectual courage is even rarer than physical courage" 24 , or Zygmunt Bauman's calls for sociological enlightenment under the postmodern risky plurality of norms and values, in a polycentric world, in an "age of noise", that is, to spot the general in the particular, to construct a larger system in which each 'makes sense' to the other, and to learn the "art of dialogue". ${ }^{25}$

I believe that such a thought-provoking text is an indicator of a good book, and I cannot help but quote the author: "That, at least, is my expert opinion, but I could be wrong" (p. 238).

\title{
Вся власть экспертам? Противоречия информационного общества, зависящего от экспертного знания, но девальвирующего его
}

\author{
Ирина Троцук \\ Доктор социологических наук, профессор кафедры социологии, Российский университет дружбы \\ народов \\ Ведущий научный сотрудник, Центр фундаментальной социологии, национальный исследвоательский \\ университет Высшая школа экономики \\ Адрес: ул. Миклухо-Маклая, д. 6, Москва, Российская Федерация 117198 \\ E-mail: irina.trotsuk@yandex.ru
}

Рецензия на: Tom Nichols, The Death of Expertise: The Campaign against Established Knowledge and Why It Matters (New York: Oxford University Press, 2017).

24. Polanyi J. C. (1987) A Scientist and the World He Lives In: Speech to the Empire Club of Canada (November 27, 1986). The Empire Club of Canada Speeches 1986-1987 (eds. C. F. Turner, T. Dickson), Toronto: Empire Club of Canada, pp. 149-161.

25. See, e.g., Bauman Z. (2000) Sociological Enlightenment - for Whom, about What? Theory, Culture \& Society, vol. 17, no 2, pp. 71-82; Tabet S. (2017) From the Modern Project to the Liquid World: Interview with Zygmunt Bauman. Theory, Culture \& Society, vol. 34, no 7-8, pp. 131-146. 